\title{
Counsellors' Competence in Managing School Related Crises in Southwestern Nigerian Universities, Nigeria
}

\author{
Lawal Oluwabukola Esther \\ Department of Educational Foundations and Counselling \\ Obafemi Awolowo University, Ile-Ife, Nigeria \\ Atoyebi Adeola Olusegun \\ Department of Educational Foundations and Counselling \\ Obafemi Awolowo University, Ile-Ife, Nigeria \\ E-mail: adeola67I@gmail.com
}

\begin{abstract}
The study ascertained the availability and adequacy of trained guidance counsellors in south-western Nigerian universities. It also investigated the common crises in the universities; determined and examined the level of counsellors' competence in managing crises in South-western universities. These were with a view to providing information on some factors that could influence crises management in the universities by universities guidance counsellors. The study adopted a descriptive survey research design. The population for the study comprised all guidance counsellors in southwestern Nigerian Universities. The sample size comprised I28 respondents in southwestern universities and three states (Osun, Oyo and Ogun) were also selected from six states (Oyo, Osun, Ogun, Ekiti, Ondo and Lagos) in southwest Nigeria using simple random sampling technique. Two instruments were used to elicited information for the study, namely: Checklist of Availability \& Adequacy of Counsellors (CAAC) and Counsellors' Competence Scale (CCS) Data collected were analyzed using percentage, chis-square and multiple regressions. The result showed that the availability and adequacy of trained guidance counsellors in Southwestern Nigeria universities were not adequate, federal $27(93.1 \%)$ state $\mathrm{I}(100.0 \%)$ and private $35(97.2 \%)$. The result also revealed common crises in the southwestern Nigerian universities showing truancy has the commonest crisis in the school with 3(4.0\%), followed by drug abuse $9(10.9 \%)$, cultism is the third one $9(10.9 \%)$ and so on. Furthermore, the result of this study showed how competent school counselors are, with federal universities having the most competent counselors $8(27.6 \%)$, followed by state university with $4(21.0 \%)$ and private university with $7(19.4 \%)$. The result showed the difference in the competence of the universities counsellor based on the institutions F-ratio $(F=3.409$ and Sig $=0.035)$, the difference in the competence of the universities counsellor based on the institutions is significant at $\mathrm{p}<0.05$.It was concluded that counselor competence had significant relationship with school crises management.
\end{abstract}

Keywords: Crises Management, Counselor Competence.

\section{Introduction}

Crisis is a temporary emotional condition wherein one's usual coping strategies have failed in face of a perceived challenge or threat in the school (i.e. university). School related crises refer to the unrest, riot health hazards, religious crises, cultisim, rape, bullying, truancy etc that do come up within the school. Disturbing school events have the potential to erupt in schools at any time. These deleterious situations may range in scope from the riot, protest or natural catastrophes such as tornadoes or floods, to emergencies such as the death of a student, damages to properties or man-made disasters such as school shootings or suicides. School crises bring chaos that undermines the safety and stability of the school and may make it difficult to protect students and staff (Allen, 2002). Furthermore, crises put individuals in a state of psychological disequilibrium with feelings of anxiety, helplessness, and confusion. Where crises do occur, impairment in problem solving abilities and academic growth has the potential to occur (Allen, 2002). Some of the examples of school related crises are; students riots, staff protest may be as a result of and non-promotion of staffs, increment in students school fees and so on. For instance, in 2018, Bowen university unrest that occurred on the 04/12/2018 where one hundred students were rusticated because they were tested on drugs use by the university management and they were found guilty of the offence and their studentship were terminated and because of this, their colleagues started burning hostels within the university in solidarity and the school was shut down immediately.

Managing school related crises may be referred to ways and methods that school counsellors have laid down to control and quench crises whenever they may occur in the university. Schools and school system are increasingly expected and legally obligated to be prepared for and respond to crises impacting school communities. However, there have been few systematic efforts to develop training programs designed to increase the crisis preparation and response abilities of school based 
professionals (competent counsellor). In addition to this general obligation to provide a safe learning environment, school systems are beginning to be held accountable for crisis prevention, preparation, and response.

Management of school related Crises may refer to the act of handling and controlling students' disorderliness in an educational institution by the management of such institutions through the help of competent and prepared counsellor. When school related crises are properly managed, there may be smooth academic calendar, secured lives and properties may be guaranteed and peace will rain in the institution. Scholar such as Alabi (2002), have written on the management of school related crises in Nigeria. According to this scholar, efforts at managing school related crises by the concerned authorities (government and institutions) often take the form of immediate closure of institutions with an ultimatum instructing students to vacate their halls of residence and premises; suspension or dissolution of students' unions and their executives. And when the crises have a national impact, the government often reacts by proscribing the Students' Union Organization at the national or state level. Other strategies mentioned by this scholar (Alabi, 2002) include rustication or outright expulsion of student leaders and the use of security forces like the police/army to maintain law and order in the affected institution.

The researcher observed that in recent times in Southwestern universities in Nigeria, school crises are at a high rate and this has been resulting in loss of lives, properties, distortion of the academic calendar, school activities and it seems school counsellors may not know how to manage those crises. The frequency with which these crises occur is alarming, leading many to believe that it is not a matter of crisis will occur in a school or school district but instead a question of when a crisis will occur, overall effects and how to manage school related crises whenever it occurs (Brock, 2002). This has become worrisome to all and sundry and this formed the premise for this study and the need for this study in the Southwestern universities Nigeria.

Over the last decade, there has been an increasing focus throughout the country on managing school related crises. In addition to the highly publicized incidences of school violence, other school crises have included the sudden, unexpected loss of a child or staff member due to injury or violence, serious injuries at school or in the community, anticipated deaths due to longterm illness, natural and industrial disasters, and acts of war and terrorism (Brock, 2002; Brock \& Jimerson, 2004).

Other factors such as teacher's factors, students' factors, environmental factors, peers' factors, family factors and so on may play good roles in managing school related crises. Differences in managing school related crises can surely be explained by differences in cognitive aptitude of school counsellors, but variables like counsellors' competence and preparedness may also be explored. The ability of a school counsellor to manage and control school crises is called counsellor competence.

It is expected of a counsellor to be competent in order to discharge the required professional duties without breach of ethics. They also bring with them varying levels of confidence to complete those duties. However, some universities counsellors may find it easy to succeed in dealing with students and riots in the school. That is they are competent. Counsellor competence is one of the variables that measure an individual's success or failure in counselling the undergraduates and handling students' unrest in the school. Counsellor's Competence may be referred to as use of a set of related knowledge and skills required to successfully perform a task, handling students, students' unrest in the school and other disasters in Southwestern Nigeria University. Competencies often serve as the basis for skills standards that specify the level of knowledge, skills and abilities required for success in the task (Rajesh, 2014).

Counsellor competence is the capability of counsellors to apply or use a set of related knowledge, skills and abilities required to be successful in a counselling task and managing school related crises. Counsellor competence may be related to abilities, skills, knowledge and dispositions of cognitive and non-cognitive nature that allow counsellors to perform their duties. This field of counsellors education has evolved over the year of practice, more recently guided by the accreditation standards created by CACREP (Council for Accreditation of Counselling and Related Educational Programs). CACREP are those standards of preparation for professional practice, the latest being dated 2016, that specify the knowledge and skills needed to offer professional counselling and managing crises that may occur at working place. From these standards, so far it has been observed that knowledge and skills comprise only two aspects of the professional practice; the third aspect being the personal qualities of the provider of those competencies of the professional counsellors. This means that the qualities of the counsellor are vital to the success of counselling and management of school crisis. Previous researches such as Corey \& Corey (2003); Campbell \& Christopher (20I2); Neukrug (20I2) have identified several personal characteristics that exemplify an effective and competent counsellor.

Professional school counsellors demonstrate competence as instructors and understand the dynamics of the classroom and the school setting. This initial experience provides the background for their understanding of school-related situations and problems and an understanding of the opportunities available in the school system. Competencies, in the most general terms, are "things" that an individual must demonstrate to be effective in a job, role, function, task, or duty. These "things" include jobrelevant behavior (what a person says or does that results in good or poor performance), motivation (how a person feels about a job, organization, or geographic location), and technical knowledge/skills (what a person knows/demonstrates regarding facts, technologies, a profession, procedures, a job, an organization, etc.). Competencies may be identified through the study of jobs and roles. 
Professional school counsellors accept responsibility for self-directed professional development through continuous efforts to improve their competence in meeting and exceeding standards in performing their jobs. Professional behavior also entails the expectation that counsellors have a responsibility to improve the inclusivity of the school environment, to maintain collaborative inter-professional relationships and make sure that law and order are maintained in the universities. Professional school counsellors demonstrate professional behavior in all components of a comprehensive, developmental guidance and counselling program; however, accountability for the time dedicated to these activities applies to the System Support component. (Allen, Burt., Bryan Carter, Orsi, \& Durkan, 2002)

School counsellors are expected to be involved in managing these crises. Successful management of such crises may require that the counsellor be competent. The effect of competence of the counsellors in universities today is not known because most universities still experience crisis. The persistence of this might be unconnected to the level of competency of the counsellors and also their preparedness in the management of these crises. There is the need for a research to establish the connectivity and inter-connectivity of counsellors' competence in managing school related crises in the university; hence this study.

\section{I.I Purpose of the Study}

The purpose of this study is to:

- Establish the availability and adequacy of trained guidance counsellors in south-western Nigerian universities;

- Investigate the common crises in the universities;

- Examine the level of counsellors' competence in managing crises in South-western universities.

\section{I.2 Research Questions}

The following questions were raised to guide the study

- How available and adequate are trained counsellors in Southwestern Nigerian universities?

- What are the common crises in the universities?

- What is the level of counsellors' competence to manage crises in South western

\section{I.3 Research Hypotheses}

The following hypotheses were postulated

- There is no significance relationship between the level of counsellors competence and prevalence of crises in south western universities.

- The difference in the competence of counsellors to manage school crises based on the institution (Federal, State and Private) is not significant.

\section{Methodology}

The study adopted the descriptive survey research design. This entails the process of gathering information from a representative sample of a population. The descriptive survey design studies characteristics and opinions of relatively small samples of a population through which it seeks to determine the incidence and distribution of such characteristics and opinions in the population. This study adopted this research design because it sought to obtain information from a representative sample of the population. The dependent variable was school related crises management. The independence variable was counsellor competence. This study seeks to find out the availability of counsellors, competence in managing school related crises in Southwestern universities in Nigeria, using a questionnaire to collect data, the descriptive survey is therefore considered appropriate for the study.

School related crises management was measured using Checklist on Availability and Adequacy of Councellors scale to establish the levels availability and adequacy of aouncellors. Also, the independence variable, Counsellors Competence was measured using Counsellors Competence scale of Chen and Gully (200I) to establish counsellors' competence.

This consists of three sections: section A is the bio-data of the respondents while section B and $\mathrm{C}$ were Checklist on Availability and Adequacy of Councellors and counselor competence scale respectively. The instruments were validated with the help of experts in Tests and Measurement and Psychology of Education at Obafemi Awolowo University, Ile-Ife. Kaiser-Olkin Measure of Sampling Adequacy (KMO) and Bartlett's Test of Sphericity (BTS) were carried out to ascertain the usability of factorial validation for the validation of the items in each section of the questionnaire and each item yielded uniform data. The Kaiser-Meyer-Olkin Measure of Sampling Adequacy (KMO) value for stigma consciousness and self-image scale were 0.85 and 0.925 respectively which is greater than critical value at 0.05 level of significance and so is acceptable. The Cronbach's Alpha approach was adopted in determining the reliability of the scale and it yielded a coefficient of 0.82I 6 and 0.756. 


\section{Results}

Research Question I: What is the availability and adequacy of trained guidance counsellors in Southwestern Nigeria universities? To answer this question, sampled counsellors' response to Section B of the study instrument was compiled and coded and the data collected were analyzed with the use of frequency count and percentage. The result is as presented in Table I.

Table I. Availability and Adequacy of Trained Guidance Counsellors in Southwestern Nigeria Universities

\begin{tabular}{lrrrr}
\hline \multirow{2}{*}{ Institution } & \multicolumn{2}{c}{ Availability of Trained Counsellors } & \multicolumn{2}{c}{ Adequacy of Trained Counsellors } \\
\cline { 2 - 5 } & \multicolumn{1}{c}{ Not Trained } & Trained & Not Adequate & Adequate \\
\hline Federal & $2(6.9 \%)$ & $27(93.1 \%)$ & $\mathrm{I} \%(65.5 \%)$ & $\mathrm{IO}(34.5 \%)$ \\
\hline State & 0 & $\mathrm{I} 9(100.0 \%)$ & $\mathrm{I}(5(78.9 \%)$ & $4(2 \mathrm{I} . \mathrm{I} \%)$ \\
\hline Private & $\mathrm{I}(2.8 \%)$ & $35(97.2 \%)$ & $8(22.2 \%)$ & $28(77.8 \%)$ \\
\hline Total & $3(3.6 \%)$ & $8 \mathrm{I}(96.4 \%)$ & $42(50.0 \%)$ & $42(50.0 \%)$ \\
\hline
\end{tabular}

The result as presented in Table. I. showed that while $6.9 \%$ of sampled counsellors in the Federal universities reported that they were not trained counsellors $2.8 \%$ of sampled counsellors in private universities reported not to be trained that is $93.1 \%$, I00\% and $97.2 \%$ of employed counsellors in Southwestern Federal, state and private universities were trained counsellors. However, $65.5 \%, 78.9 \%$ and $22.2 \%$ of the sampled Southwestern State Federal, State and private universities guidance counsellors respectively were of the opinion that the available trained guidance counsellors in the universities were not adequate.

Research Question 2: What are the common crises in the study area?

To answer this question, sampled guidance counsellors' response to Section $\mathrm{C}$ of the study instrument were coded and analyzed using frequency count and percentage to establish the occurrence of the identified common crises. This was followed by determining the most to the least common of the identified crises us RSI. The result is as presented in Table 2.

Table 2. Counsellors Identified Common Crises in the Study Area

\begin{tabular}{lcccc}
\hline Identified Common Crises & No & Yes & RSI & Rank \\
\hline Health Hazard & I5(I7.8\%) & $69(82.2 \%)$ & $0.91093 \mathrm{I}$ & 8 \\
\hline Religious Crises & $24(28.3 \%)$ & $60(71.7 \%)$ & 0.8583 & $\mathrm{II}$ \\
\hline Rape & $22(26.3 \%)$ & $62(73.7 \%)$ & $0.86842 \mathrm{I}$ & $\mathrm{I} 0$ \\
\hline Harassment & $\mathrm{II}(\mathrm{I} 3.0 \%)$ & $73(87.0 \%)$ & 0.935223 & 7 \\
\hline Cultism & $9(\mathrm{I} 0.9 \%)$ & $75(89.1 \%)$ & 0.945344 & 3 \\
\hline Emotional Distress & $\mathrm{II}(\mathrm{I} 3.0 \%)$ & $73(87.0 \%)$ & 0.935223 & 6 \\
\hline Bullying & $\mathrm{II}(\mathrm{I} 2.6 \%)$ & $73(87.4 \%)$ & 0.937247 & 4 \\
\hline Psychological Disequilibrium & $\mathrm{I} 9(22.7 \%)$ & $65(77.3 \%)$ & 0.88664 & 9 \\
\hline Drug Abuse & $9(\mathrm{I} 0.9 \%)$ & $75(89.1 \%)$ & 0.945344 & 2 \\
\hline Truancy & $3(4.0 \%)$ & $8 \mathrm{I}(96.0 \%)$ & 0.979757 & $\mathrm{I}$ \\
\hline Sexual Violence & $\mathrm{II}(\mathrm{I} 3.0 \%)$ & $73(87.0 \%)$ & 0.935223 & 5 \\
\hline
\end{tabular}

The result as presented in Table 2 showed that $96.0 \%$ of the sampled counsellors were of the opinion that "truancy" is the most common crises in the study area and its rank first among the identified crises. 'Drug abuse and 'cultism were ranked second and third of the common crises in the study area respectively while 'bullying' and 'sexual violence' were ranked fourth and fifth with $89.1 \%$ and $87.4 \%$ of the guidance counsellors respectively reporting them as common crises. Table 2 also showed that guidance counsellors ranked 'Psychological Disequilibrium 'rape' and 'religious crises' as ninth, tenth and eleventh most common crises in the Southwestern Nigerian universities respectively.

Research Question 3: How competent are Southwestern Nigeria universities counsellor in the management of school crises? To answer this question, sampled counsellors' responses to Section D items of the study instrument were scored and the scores were used to determine the level of competence. On the scale the minimum and maximum scores obtained were 35 and 53 with a mean and standard deviation $(\bar{X}=45.40 . \mathrm{SD}=5.42)$ scores. Counsellors with scores that ranged between the minimum and 
the mean minus one standard deviation (35-40) were categorized as 'Not competent' while counsellors with scores that is greater than the mean minus one standard deviation but less than the mean plus one standard deviation (4I -50) were categorized to be 'averagely competent' and those with scores that ranged between the mean plus one standard deviation and the maximum score (5I-52) were categorized to be at 'highly competent'. With the use of frequency count and percentage, a number of counsellors in each preparedness level was determined and presented in Table 3.

Table 3. Competency of Southwestern Nigeria Universities Counsellor in the Management of School Crises

\begin{tabular}{lrrrr}
\hline \multicolumn{1}{c}{ Competency of University Counsellors } & Total \\
\hline Federal & Not Competent & $\begin{array}{c}\text { Averagely } \\
\text { Competent }\end{array}$ & $\begin{array}{c}\text { Highly } \\
\text { Competent }\end{array}$ & \\
\hline State & $6(20.7 \%)$ & $15(51.7 \%)$ & $8(27.6 \%)$ & 29 \\
\hline Private & $6(31.6 \%)$ & $9(47.4 \%)$ & $4(21.0 \%)$ & 19 \\
\hline Total & $9(25.0 \%)$ & $20(55.6 \%)$ & $7(19.4 \%)$ & 36 \\
\hline
\end{tabular}

Table 3 showed that while $21.0 \%$ of the sampled counsellors were not competent to manage occurring school crises, $52.4 \%$ and $22.6 \%$ of them were averagely and highly competent for the management of school crises. Table 3 also showed that $27.6 \%$ of counsellors in the Federal universities were highly competent while $21.0 \%$ and $19.4 \%$ of counsellors in State and private universities respectively were highly competent for the job of managing school crises as they occurred.

Hypothesis 3: The difference in the Competence of counsellors to manage school crises based on the institution (Federal, state and private) is not significant

To test this hypothesis, the difference in sampled counsellors' scores on section D items of the study instrument was determined using One-way Analysis of Variance (ANOVA) and the result is as presented in Table 4.

Table 4. Difference in Southwestern Nigeria Universities Counsellors' Competence in Managing School Crises Based on Ownership (Federal, State and Private)

\begin{tabular}{lrrrrr}
\hline & Sum of Squares & Df & Mean Square & F & Sig. \\
\hline Between Groups & 196.512 & 2 & 98.256 & 3.409 & .035 \\
\hline Groups & 2363.404 & 82 & 28.822 & & \\
\hline Total & 2559.916 & 84 & & & \\
\hline
\end{tabular}

The result as presented in Table 4 showed that with the F-ratio $(F=3.409$ and Sig $=0.035)$, the difference in the competence of the universities counsellor based on the institutions is significant at $\mathrm{p}<0.05$. Therefore a post hoc test of multiple comparisons was carried out to identify where the difference lies between the institutions. The result is presented in Table 4.

\section{Discussion of Findings}

Counsellors are expected to be endowed with school crises management skills which requires competency and adequate preparedness. However, the preparedness and competency of most university counsellors are not ascertained at the point of employment and even in the course of discharging their duties. This study therefore established the connectivity and interconnectivity of counsellors' competence and preparedness in managing school related crises in the university across Southwestern states of Nigeria.

The findings of the study with respect to research question one showed that majority of employed counsellors in Southwestern federal, state and private universities were trained however, the available university counsellors were not adequate in relation to students' population. The inadequate availability of counsellor as discovered in this study is in line with Tambawal (2007) report of inadequate availability of relevant equipment and facilities needed for running counselling services in the schools. The inadequacy in the availability of counsellor may be as a result of Okere (2005) observation of improper funding of counselling services in schools.

Though there is an inadequate availability of counsellors in the Southwestern universities as reported in the study, the available counsellors in the Southwestern universities were found to be less prepared but competent for the job of managing school crises as they occurred. These findings were in line with Brock, (2002) findings which said that counsellors are usually 
prepared to manage school related crises and Maxwell (2014) who found out that, school counsellors demonstrated above average level of competencies, while non-school setting counsellors demonstrated below average competencies in the areas of human development and growth physical, cognitive, and psychosocial aspect of human development. School counsellors demonstrated above average in competencies relating to theories of learning and personality development, while non-school setting counsellors demonstrated below average. Which means that Counsellors in the school and non-school settings are professional in the field of counselling, and are expected to have competencies in the areas of helping relationship, client assessment, human growth and development, and professional orientations and ethical practice. Furthermore, the findings collaborate with the studies of Anagbogu \& Nwokolo (2010) and Oraegbunam (2008) who had earlier listed similar challenges in their previous work. The respondents, however, disagreed totally with the item which stated "incompetence on the part of the counsellors". The disagreement on the part of the respondents probably may be due to the fact that they do not want to underrate their ability to deliver effective counselling skills and techniques. When counsellor is competent, this means that the counsellor possessed the needed skills, knowledge and methods to curb and manage school related crises whenever they occurred and this is in line with (Brock \& Brock 2002; 2004) study which stated that crises related will be well managed and prevented when a counsellors is competent, and competence of a counsellors means that possessing required skills, knowledge and abilities to manage crises.

The finding of the present study also showed that truancy, drug abuse, cultism, bullying and sexual violence were the common crises in the Southwestern Nigerian universities. The finding was in agreement with Nwadiani (I994), Oghuvbu (2006) and Ogbuvbu (2010). They found out that truancy, drug abuse and sexual violence could result into poor academic achievement, loosing friends and parties and disruption in class. However, this finding was contrary to the findings of (Allen, 2002) which stated that indiscipline is the common crises that usually occur in the school.

\section{Conclusion}

The present study established that majority of guidance counsellors in the tertiary institutions in Southwestern Nigerian universities possessed a moderate level of competence and are ready for crises management in the school. It further showed that 'truancy' is the most common crises in the study area. The study also concluded that counsellor competence could enhance crises management. Finally, it was concluded that crises management depended on the influence of counsellor competence.

\section{Recommendations}

Arising from the findings and conclusion of this study, following recommendations were proposed to further enhance crises management in Southwestern Nigerian university, which will result to crises free in the universities, smooth academic calendar and secured lives and properties within the school. Therefore, this study should be applied to various educational and counselling settings. These recommendations are given subsequently.

There is a need for university guidance counsellors to make realistic commitments to their duties with the intension to be successful in managing school crises. It is also important that university guidance counsellors should be competent and prepared to manage crises within the school whenever it occurs. Counsellors' Associations should organize periodic academic seminars for university guidance counsellors on how to be competent, prepared and these will help them in managing school crises whenever they occur. Government and owners of private universities should also encourage university guidance counsellors to possessed competence skills and get prepared to manage crises within the school whenever they occur and this will make them be successful at it.

\section{References}

Allen, M., \& Ashbaker, B. Y. (2004). Strengthening schools: Involving paraprofessionals in crisis prevention and intervention. Intervention in School and Clinic, 39, I39-I46.

Allen, M., Burt, K., Bryan, E., Carter, D., Orsi, R., \& Durkan, L. (2002).School counsellors' preparation for and participation in crisis intervention. Professional School Counselling, 6, 96-102.

Allen, M., Jerome, A., White, A., Marston, S., Lamb, S., Pope, D., \& Rawlins, C. (2002). The preparation of school psychologists for crisis intervention. Psychology in the Schools, 39, 427-439.

Alabi G. G. (2002). Crisis response in the public schools: A survey of school psychologists' experiences and perceptions. Psychology in theSchools, 44, 749-763.

Anagbogu .Z.A, et.al Nwokolo. (2010) \& Oraegbunam. (2008). Managing in a Pareto world calls for thinking. Management, I4(2), 89-II8.

Brock, S. E. \& Poland, S. (2002). School crisis preparedness. In S. E. Brock, P. J. Lazarus, \& S. R. Jimerson (Eds.), Best practices in school crisis prevention and intervention (pp. 273-288). Bethesda, MD: National Association of School Psychologists. 
Brock, S. E., \& Jimerson, S. R. (2004a). Characteristics and consequences of crisis events: A primer for the school psychologist. In E. R. Gerler Jr. (Ed.), Handbook of school violence (pp. 273-284). New York: Hawthorn Reference Press.

Brock, S. E. (2002a). Crisis theory: A foundation for the comprehensive crisis prevention and intervention team. In S. E. Brock, P. J. Lazarus, \& S. R. Jimerson (Eds.), Best practices in school crisis prevention and intervention (pp. 5-I8). Bethesda, MD: National Association of School Psychologists.

Corey, G., Corey, M. S., \& Callanan, P. (1998). Issues and ethics in the helping professions (5th ed.). Pacific Grove, CA: Brooks/Cole.

Corey, M.S., \& Corey, G. (2002). Groups: Process and practice (6th.ed.). Pacific Grove,CA: Brooks/Cole.

Corey, M.S., \& Corey, G. (2003). Becoming a Helper.(4th.ed). Pacific Grove. CA.Brooks/Cole.

Maxwell. D. E. (2014). Professional competency among School and non-school counsellors In Rivers State, Nigeria. Singaporean journal of business economics, and management studies, $3(4)$.

Nwadiani M. (1994). Managing pupil's attendance data for computerization. A Paper Presented at the NIERA Computerization of Educational Data Conference, University of Benin, 2I-24 June.

Okere A. (2005). The effective school counsellors: Perception of students, teachers and counsellors. J. Educ. Foundations, I, I47-I52.

Tambawal, M.U. (2007). Counselling for effective management of human resources. Paper presented at the 2007 CASSON conference at Ota, Ogun State. August. I4 - I7.

\section{Copyrights}

Copyright for this article is retained by the author(s), with first publication rights granted to the journal. This is an open-access article distributed under the terms and conditions of the Creative Commons Attribution license (http://creativecommons.org/licenses/by/4.0/). 